\title{
Dialectic of essentialism and constructivism in modern sociohumanistic research (illustrated by ethical and religious range of problems)
}

\author{
Zhanna Latysheva*, Evgeniy Arinin, Nikolai Petev, Viktor Barashkov \\ Vladimir State University named after Alexander and Nikolay Stoletovs, 600000, Vladimir, Russia
}

\begin{abstract}
The article defines the possibilities and character of complex application of essentialist and constructivist approaches in the study of socio-humanistic processes and phenomena. Modern scientific methodology should abandon the "shallow", one-sided rational thinking, incapable of encompassing and comprehending multi-faceted, complex and ambivalent social and individual reality. The study of productivity of interrelated essentialism and constructivism methodologies in concrete scientific inquiry is one of the steps in this direction. The subgoal of this article is to broaden and refine the knowledge regarding the potential linking of essentialist and constructivist attitudes in specific scientific socio-humanistic research. The general goal and novelty of the article is the preparation of theoretical background to develop the current modern version of the multidimensional rationality concept of the human with multifaceted objectives and activity. These goals are reached by determining the productivity/unproductivity of one-sided absolutization of the above approaches in the analysis of modern socio-humanistic processes and phenomena and by clarifying their complementarity and its character. On the basis of addressing essentialist and constructivist traditions of describing Orthodoxy and Christianity at large, consideration of fundamentalism phenomenon in various denominations, comparison of essential and constructivist-mythological approaches to ethic phenomena analysis, the conclusion is made that the tradition of clear division between essentialism and constructivism is becoming irrelevant; comprehensive and therewith multi-criteria analysis of modern socio-humanistic range of problems suggests defining both its permanent essential component and its dynamic, constructing trends. These approaches should be used in their dialectic unity: inviolability of fundamental cultural values and their new "integration" in changing social life conditions every time constitute the most important condition for creative constriction and study of social reality.
\end{abstract}

\section{Introduction}

The whole history of philosophy is permeated with the ever modifying and dialectically developing search for the solution of problems of knowledge essence, the relationship of

*Corresponding author: joan_lat@mail.ru 
rational and irrational, true and illusory in the world and human knowledge and being. These problems in one form or another were raised by the greatest minds of Ancient Greece, India, and China. Along with the formation and establishment (since the XVIII century) of the scientific knowledge apodicticity ideal based on the logical, mathematical, and scientific types of academic rationality, one detects its active criticism in the modern and contemporary periods; the criticism growth signifies the crisis condition of this rationality, which has lasted for more than a century already.

Nowadays more than ever one perceives the inadequacy of the narrow scientific worldview, as well as the impossibility to fit the universe of human society and culture in the sub-universe of science, the importance of finding new study angles and vectors, of solving scientific problems in the wide sociocultural and humanitarian context on the integrative basis of materialistic and idealistic forms of ontology, gnoseology, philosophic anthropology, science philosophy and methodology, ethics, philosophy of religion, philosophy of art, and other fields of philosophy. In this connection the appeal of $\mathrm{P}$. Sorokin regarding the importance of study in the field of idealistic, mystical and supersensory philosophy (Sorokin, 2014, p. 284) becomes prominent. Modern scientific methodology desperately needs the revision of its traditional foundations and viewpoints as well as the final abolishment of long-outdated positivistic-pragmatic and utilitarianhedonistic attitudes, stereotypes, and values, which have become the sources of crises in various spheres of social life. In this respect, special attention should be given to interdisciplinary studies, in particular, to the study of various forms of interaction between ethics, religion, and art.

The resulting poly-aspect and multilayer domain of scientific studies will promote the formation of modern variants of the concept of multi-dimensional open rationality of holistic, inexhaustible in its pursuits and manifestations human and its socio-cultural life.

\section{Research Objective}

With the objective of perspective development of such concept version, we shall review one of the fundamental methodological problems of this research area - the opposition problem of essentialism (substantialism) and constructivism as the established approaches to the analysis of sociohumanistic phenomena and processes. The object of analysis shall be the phenomena of religion (Orthodoxy and Christianity at large) and ethics as adequately comprehensive and demonstrative in their essentialist and constructivist study. We shall try to answer the following questions: How productive is the one-sided absolutization of these approaches in social structure planning and study of religion and ethics? Are they strong antagonists or dialectical supplements for one another? The study of this problematics is based on its statement and development by Plato and Aristotle in Antiquity, by Thomas Aquinas and other realists of the Middle Ages, by the modern and contemporary times scholars R. Descartes, G. Hegel, E. Husserl, M. Scheler, K. Popper, by the criticism of essentialism by medieval nominalists, G. Berkeley, D. Hume, I. Kant, A. Comte, E. Mach, J. Dewey, W. Bridgman, etc. The researchers of the last decades and years focus either on essentialist (Arinin, 1998; Gusejnov, 2012; Smart, 1998), or on constructivist types of analysis (Voroncova, 2014; Kolkunova, 2014; Latysheva, 2014, 2016; Matushanskaya, 2015; McKinnon, 2002), thereby contrasting them. D. Dobrynin (Dobrynin, 2019) also builds his arguments on the division of essentialist and constructivist approaches to the definition of religion without addressing their interaction. The authors of this research while continuing the study of these important approaches in religious studies and ethics also attempt to understand their relationships. 


\section{Methods of Study}

The choice of methodology and methods of study is contingent on the specifics of the established problem and the logics of problem solving. The analysis is based on the achievements in the area of essentialism, social constructivism, system and structurefunctional approaches with the use of the broad spectrum of classical and modern philosophical and ethical (B. Spinoza, F. Nietzsche, R. Barthes, M. Bakhtin, A. Gusejnov, P. Matveev, N. Petev), religious and ethical (E. Arinin, I. Davydov, A. Aleksandrova, S. Ivanov, Zh. Latysheva, A. Shoufrine, B. Daelemans, J. Koestlé-Cate, D. Morgan, E. Rosen, J. Elkins, etc.), as well as social philosophic and sociological (N. Luhmann, J. Habermas, M. Silantieva, V. Glagolev, B. Tarasov) works. The article, while abiding by the principles of historicism and systematicity, applies essentialist, constructivist, and structural analysis, dialectic, and comparative methods.

\section{The potential of essentialism and constructivism in the study of Christianity (Orthodoxy)}

First of all, let us point out that the term "Orthodox Christianity" in the modern Russian culture (according to the "New Russian Encyclopedia") defines the most representative religious tradition of our country, involving the majority of citizens of the modern Russian Federation (Zuev, 2014, p. 63). Similar definitions are found in professional publications in religious studies: Encyclopedic Dictionary "Religious studies" (Davydov, 2006, p. 781) and "Encyclopedia of Religions" (Zuev, 2008, p. 984).

The scientific literature and mass media have two traditions of describing Orthodoxy, one of which is inclined to essentialism, the other - to constructivism. In the framework of the first tradition, the authors focus on defining a certain unchanging "essence" or "nature" of this social phenomenon, while in the framework of the second - on the analysis of characteristics of its image changes in certain social contexts. Thus, the understanding of "essence" of some architectural constructions in Vladimir will be distinctly different not only throughout history, but also for several social groups of our contemporaries, among which there are people who first of all consider the buildings "their own" and qualifying them as "house of prayer", secondly, people considering them "strange" and qualifying them as "historical monument", and thirdly, people considering them "very strange", for example, some representatives of Neopaganism, for whom the buildings may appear as symbols of "alien faith" and "totally foreign" (Arinin, 2017a, p. 25-26).

In this way, there are three architectural constructions (church, temple, cathedral) in Vladimir that are called "Uspenskiy" (Assumption). The first and the world-famous one, featured in UNESCO World Heritage List, is the Holy Assumption Cathedral of Vladimir Diocese of Russian Orthodox Church. The second, less famous, but nonetheless considered "the most significant monument of Vladimir architecture of the XVII century" is the Temple in the name of Assumption of the Holy Mother of God, located at the address 106a Bolshaya Moskovskaya street, Vladimir. It was assigned to the community of the Russian Orthodox Old-Rite Church in 1995. The third is the almost unknown Church of Assumption of the Holy Mother of God - the old building of the church of the $10^{\text {th }}$ Grenadier Guard, built in 1907, located at the address 2v Manezhnyi tupik. Some civil organizations occupy the building now.

Understanding of "essence" of these objects will vary for several social groups of modern "observers of reality". The first two buildings are "houses of prayer" ("My house is a house of prayer", Lk. 19:46) for the worshippers of the Russian Orthodox Church and the Russian Orthodox Old-Rite Church, unlike the third one, which is not recognized as such, being only an "architectural construction" and little-known "historical monument". At the 
same time, for some of the Communist party propagandists (or protesters) all these "churches", "temples" and "cathedrals" are still the manifestations of "obscurantism" as in the soviet times (Arinin, 2017b, p. 5-6). The archive of the Department of Philosophy and Religious Studies of Vladimir State University has the photo showing pavement writing "THERE IS NO GOD, VOTE FOR COMMUNISTS" before 2013 elections in Vladimir (that is poetically called "the stronghold of Orthodoxy" by some media sources). As opposed to this, some "champions of Orthodoxy" see them as indisputable sacred places of national belief, requiring adequate finding from the regional and federal budget for their maintenance, keeping and development. At the same tome some other "champions of Orthodoxy" may consider these temples as "sanctuaries of dissenters and heretics" (Russian Orthodox Church and Russian Orthodox Old-Rite Church for one another). And the fairly recent "enthusiasts of ancient Slavic belief revival" (Neopaganism) perceive these buildings as a vivid symbol of "foreign faith" forced upon people for more than 1000 years; some may even throw improvised explosive devices into it (The official site RIA Novosti, 2009).

N. Luhmann's concept of autopoietic systems (Niklas Luhmann, 1927-1998) helps to understand how the study of religion may perceive "own", "strange" and "totally foreign" not as eternal "essence" or "nature", but as coexisting social constructions that appear and transform, forming the "tolerant", "intelligent", "self-critical" religiousness, maintaining the norms of the Constitution of the Russian Federation (1993). It is important to analyze the "fundamentalism" subculture, which aims to define and divide the manifestation of "own", "strange" and "totally foreign". "Fundamentalisms" are characteristic of any denomination; this is a feature of the "contemporary time", when, as N. Luhmann points out, "one can state: this is my world, we consider this and this right" and "encountered resistance becomes rather a reinforcing motive, it may promote radicalization and doesn't lead to questioning the reality" (Luhmann, 2012, p. 162). This sociologist (one of the major sociologists of the XX century) pointed out that "fundamentalisms are new phenomena of the last decade; this is not about 'deeply rooted' traditional attitudes, but about the successful persuasion on the part of intellectuals, among whom the identification problem may be detected". "As opposed to the older 'enthusiasm', there is no need to draw upon divine inspiration or give in to the opposite statement of illusiveness of reality" here, just "fusing personal views of reality together with personal identity and approving it as a projection is enough", because "reality does not require consensus any longer" (Luhmann, 2012, p. 162).

Fundamentalisms reflect the views on the subcultures, where it is "common to consider the functioning religion as the foundation of stability in the society", which means that "enforcement of religious conformity" should be "universal" (Dejvis, 2006, p. 6). Thus, Christianity, declaring itself a special essential community, gathering "sons of light" (or ylo

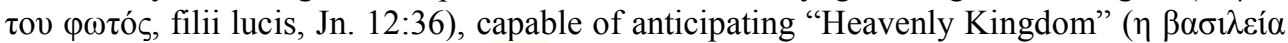

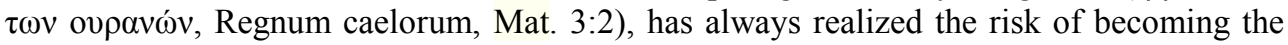

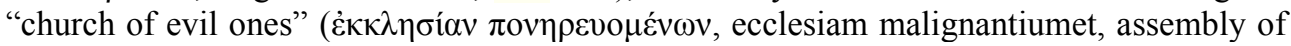

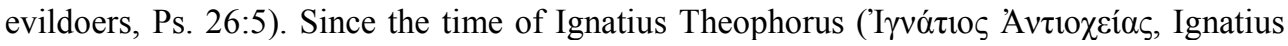

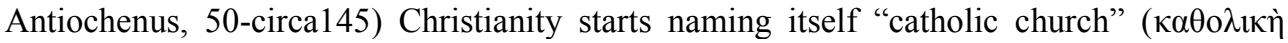

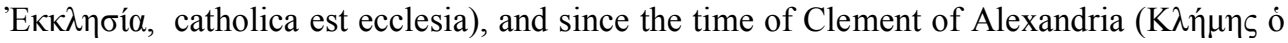

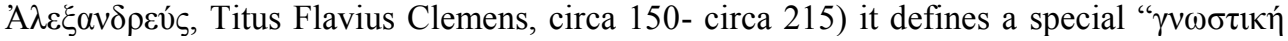

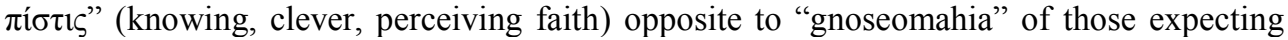

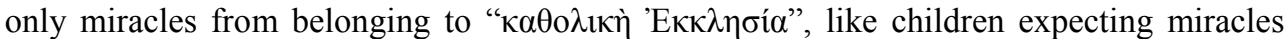
from the "Fairy godmother" in the famous film "Cinderella" (1947), the fabulous universalism and charisma of which are rooted in the spirit of the age, when it was approved ("Lenfilm" studios expert board session on 29 May 1945), in the atmosphere of emotional excitement, "freedom" and "enlightenment", caused by international union of the new "sons of light" that overcame "sons of darkness" represented by "Deutsches Reich". 


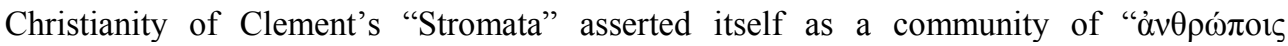

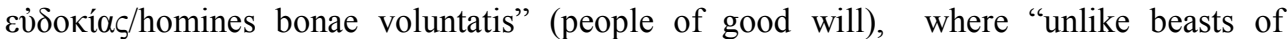

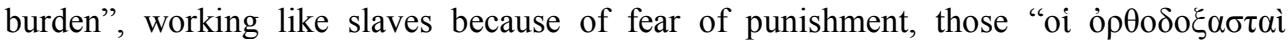
$\kappa \alpha \lambda o v ́ \mu \varepsilon v o i "$ (calling themselves "Orthodox" //"right-thinking") should "do good deeds themselves, having clear understanding of what they are doing" (198 A.D.) (Shoufrine, 2013, p. 236-237). The situation with understanding the "essence" (nature) of Christianity becomes even more complex from the time it is approved by the government in

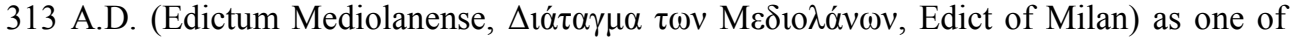
the permitted "religio" in Imperium Romanum/B $\alpha \sigma i \lambda \varepsilon i ́ \alpha$ 'P $\omega \mu \alpha i \omega v$, which after Concilium

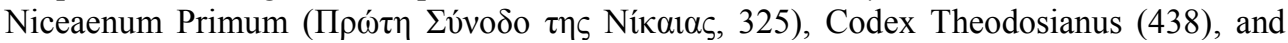
Codex Iustiniani (529) becomes a unique empire identification project "one country, one

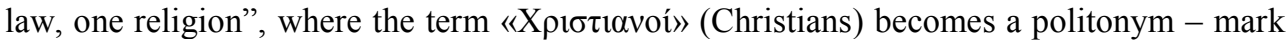
of allegiance in the Romei Empire (Ivanov, 2012, p. 278-282).

Therefore we see, that the essence of Orthodoxy and Christianity at large cannot be defined "absolutely" and "definitively" if it is defined from the viewpoint of essentialism and the principle of universality and necessity. Although there still is a creedal-dogmatic essential core in the phenomenon of religion. Therefore it is justified to divide the notions of "creedal-dogmatic essence of religion" and "sociocultural essence of religion". Understanding of sociocultural essence of religion always correlates with historical (cultural-historical, sociohistorical age), sociocultural (belonging to a certain culture, subculture, social community or group, etc.), personally subjective (worldview, selfidentification, etc.) factors. Sociocultural essence of Christianity is flexibly and productively constructed in the course of formation of religiosity and religion as objective and subjective social reality, therefore creedal-dogmaic essence appears in the form that is always relevant to the concrete sociohistorical age for a concrete sociohistorical organism. Therefore, in our opinion, methodological approach of unity of creedal-dogmatic and sociocultural essential aspects of religion appears more balanced, justified and fruitful in respect of complex study and understanding of religion.

\section{The Essence of Morality and Attempts of its Modern Construction}

Along with religion, morality also undergoes the process of active social construction nowadays as a practical field of human activity. However, this construction is carried out in the form of artificial mythologization (Petev, 2018). Modern social, economic, and political myths give rise to a special form of morality, which in its essence turns out to be a denial of ethical standards. At the same time, certain features can be seen in such "mythologized" morality.

First, it has an accident character, both in the form of moral consciousness, behavior, and attitude, and in the form of moral values. However, A.A. Gusejnov pointed out that pure moral motives are devoid of chance, as opposed to empirical (non-moral) motives (Gusejnov, 2012, p. 703-704). Second, moral decisions and actions are not individual now, whereas M.M. Bakhtin noted that a responsible act is such when oughtness and singularity are present (Bakhtin, 2003, p. 40), and the latter can take place only in individual act implementation. Modern individual seeks to form a passive paradigm of behavior and attitude, and to use the already formed principles arising from others but not from themselves.

Third, the morality of a modern individual is an existential alibi, which in particular manifests itself in the denial of responsibility and individuality. Individual begins to justify their behavior and decisions by modern customs, excluding themselves as a source of this behavior. Fourth, modern morality, or more precisely hyperbolic and categorical 
moralization, is a form of "drapery" of demoralization. R. Bart pointed out the practice of "vaccination against evil" in the modern world, when the inherent evil is redeemed by transcendent good, and the fight against lesser evil eliminates the realization of greater one (Bart, 2014, p. 107). In this system, the immoral takes the form of moral norm (virtue), and vice versa. Fifth, the issue of morality for modern man is related to usefulness. B. Spinoza showed that the more benefits people seek for themselves, the more they are gifted with moral power (Spinoza, 2001, p. 232). However, it is worth pointing out that morality is more often associated with the person's deprivation of utilitarian goods than with obtaining them. Sixth, moral value in the mind of a modern individual is identical to the concept of price (value). F. Nietzche wrote that value of something is determined by what it costs (Nietzsche, 2014, p. 99-100). In other words, what price someone is ready to give for something, the identification of price and value. However, according to P. E. Matveev, price and value are completely different things, the latter possesses individual characteristic as opposed to the average characteristic of price, which is determined by market and production relations (Matveev, 2004, p. 27).

Besides, the special egocentric factor of modern values, including moral ones, should be pointed out. Only something accessible to one, but not all is considered a value. Therefore morality becomes something outward, existing only in publicity. It is also worth mentioning that morality within the framework of consciousness mythologization becomes a phenomenon of fashion, socially popular, and therefore the elements and concepts of morality - as everything under laws of fashion - are amended and changed depending on the aspect of popularity.

With all that said, it can be affirmed that the constructivist-mythologizing model of morality leads to "deconstruction", collapse of the latter. Indeed, modern moral feeling manifests a specific symptom of decay: oughtness refers to others, but not to the individual; the individual has rights, but not duties. The concept of absolute morality is either excluded or its internal content is deformed. In the second case, the universality of morality, which is particularly reflected in the failure to form a specific and strict (legal) definition, is used speculatively to disintegrate and secularize individual's consciousness. Absence of notions of absolute morality is only a part of the moral issue. Lack of relative morals of the majority (group, society, etc.) leads to each individual becoming a maker of their own system of values and moral norms, which can have negative consequences for both the individual and the society. It is obvious therefore, that description, study and reproduction of ethical phenomena cannot do without essentialist approach, since morality itself, both secular and religious, assumes some immutable moral constants and measures. At the same time, sociocultural construction of morality coupled with historical, social and subjectivepersonal factors, where the trend of decay and mythologisation described above is minimized, also remains an integral aspect of morality interpretation.

In this regard, it is important to note that one of the natural and significant ways of absolute ethical values' rehabilitation and support now is the dialogue of contemporary artists with church (Elkins, 2004; Koestlé-Cate, 2016; Rosen, 2017). The trends of increasing role of religion in society and availability of many alternative religious projects (from fundamentalism to New Age) observed by modern scholars (Habermas, 2001) match the plastic arts language dynamics. The artistic language of the 20th-21st centuries as a whole presents the alternative to the rationalized and sometimes ideologized world of collective and individual consciousness. Throughout the 20th century, artists abandoned their classical approaches, fighting for artist's autonomy and freedom to experiment. Modern artists primarily do not turn to reason, but to the human feelings, to personal aesthetic experience, and to spiritual experience in general. While the vectors of modern art development are assigned by the art market (among other things influencing the selected topics, the means of expression, the labeling of the work as "artistic" or not (Elkins, 2004)), 
creative pursuit in plastic arts is multidimensional and not based on a single ideology (Barashkov, 2018).

Increasingly, Christian churches in Europe and America exhibit works by artists referring to perennial problems of life, death and revival (Bill Viola), tragic events of the 20th century (Christian Boltanski), human inner spiritual light (James Turrell), his rise to "heaven" (Stefan Knor). At the same time, the appeal to the transcendent takes place through artistic interpretation of the immanent (Alexandrova, 2017; Morgan, 2004). Artistic language appeals to the feelings of humans, their bodily (phenomenological) experience, their holistic self-perception as an individual. In the interpretation of modern philosophers and architects (Daelemans, 2015), church space is becoming a place of self-transcendence, extension of personal being (Erne, 2017), where aesthetic, ethical, and religious dimensions are closely intertwined.

\section{Conclusion}

Thus, the analysis testifies that not only "fluidity", "constructability", "plasticity" tendencies of phenomena and processes should be defined in socio-humanistic research, but also essential aspects of their stability and constancy. Not surprisingly, the main requirement of such stability today does not come from religion, which was traditionally responsible for "perpetuity" and harmony of space and human order, for stability of statements and norms, but in the modern era it was "privatized" (T. Parsons) and became largely uninstitutionalized, "invisible" (T. Luckmann) human religiosity. This requirement of stability stems from ethics, which is simply degrading and degenerating due to removal of essential dimensions, "the vertical", absolute, and transcendent from its structure.

Nowadays, it is not always productive to rigorously contrast essentialism and constructivism. Modern society's autopoiesis includes both construction dynamics and constancy of ideals and values, especially spiritual-humanistic ideals and values of culture as a "complex integrator of the complex society" (Silantieva et al., 2017, p. 65). It is the constancy of ideals and values of ethics (both secular and religious) and religion in the conditions of permanent spatial and temporal, social and historic, social and cultural changes that substantially becomes the border line dividing sociocultural and biological, culture and pseudo-culture, culture and anti-culture, human and anti-human.

The article is prepared in the framework of research under the grant of the Russian Foundation for Basic Research (RFFI), 18-011-00935

The research is carried out in the framework of "Philosophical Religious Studies as a 'Glocal' Project: Youth of Germany and Russia in Dialogue on Religion" project, which was supported by the grant of the Russian Foundation for Basic Research (18-011-00935 A, 2018-2020). It focuses on the issues of forming local identities combining "religion", "science", and "education" emerging in the provinces after the collapse of the USSR (1991) and of establishing the norms of freedom of conscience in modern Russia (Constitution, 1993). We present the provinces in the order of their becoming a part of the modern Russian Federation: Vladimir (990), Moscow (1147), Kazan (1552), Orel (1566), Arkhangelsk (1584), and Ulan-Ude (1666). These cities act as urban centers with the concentration of political, economic, educational, and religious elites, supporting and reproducing the "collective memory" of "Pax Christiana", "Pax Islamica", "Pax Buddhica", "Pax Khazarica", "Pax Tatarica", and "Pax Sovietica" in global, local, and "glocal" forms of their construction in the system of the state school education (since 2012 - the course "Fundamentals of religious cultures and secular ethics").

\section{References}


1. A. Alexandrova, Breaking resemblance: the role of religious motifs in contemporary art (Fordham University Press, New York, USA, 2017).

2. E. I. Arinin, "Religion, philosophy of religion and "glocal religious studies": between "exotic", "conscience" and "professionalism" (to discussions at congresses of Russian researchers of religion)”, Voprosy` filosofii, 4, 25-36 (2017).

3. E. I. Arinin, I. D. Nefedova, A.S. Timoshchuk, and O.N. Shadrina, "Religion" in the Russian context: notion, denotations, connotations", European Journal of Science and Theology, 13 (5), 5-22 (2017).

4. E. I. Arinin, Philosophy of Religion. Principles of essential analysis, Izdatel"stvo Pomorskogo gosudarstvennogo universiteta im. M.V. Lomonosova, Arhangel"sk, Russia, (1998).

5. M.M. Bakhtin, Collected works in 6 volumes, 1 (Russkie Slovari, Moscow, Russia, 2003).

6. V. Barashkov, Main Trends of Aesthetical Modernization of Christian Religious Images in Europe at the beginning of the $21^{\text {st }}$ century, Study of Religion, 2, 122-130 (2018).

7. R. Bart, Mythologies (Akademicheskij proekt, Moscow, Russia, 2014).

8. A.A. Gusejnov, Philosophy - thought and action: articles, reports, lectures, interviews (SPbGUP, Saint-Petersburg, Russia, 2012).

9. Yu.P. Zuev, Orthodoxy, Encyclopedia of religions (Akademicheskij proekt, Moscow, Russia) 984-990 (2008).

10. Yu.P. Zuev, Orthodoxy, New Russian Encyclopedia, XIII (2) (Moscow, Russia) 6367 (2014).

11. B. Daelemans, Spiritus Loci: a Theological Method for Contemporary Church Architecture (Brill, Leiden, Boston, USA, 2015).

12. I.P. Davydov, Orthodoxy, Religious Studies, Encyclopedic Dictionary (Akademicheskij proekt, Moscow, Russia) 781-783 (2006).

13. D. Dejvis, The United Nations Declaration "On the Elimination of All Forms of Intolerance and Discrimination Based on Religions or Beliefs" as a Factor for the Protection of Religious Freedom, Svoboda sovesti v Rossii: istoricheskij i sovremennyj aspekty, 3, 5-17 (2006).

14. D. Dobrynin, Essentialism and Constructivism in Approaches To Defining Religion, Koncept: filosofija, religija, kul'tura, 2 (10), 65 - 71 (2019).

15. J. Elkins, On the Strange Place of Religion in Contemporary Art (Routledge, New York \& London, UK, 2004),

16. Th. Erne, Hybride Räume der Transzendenz. Wozu wir heute noch Kirchen brauchen. Studien zu einer postsäkularen Theorie des Kirchenbaus [Hybrid spaces of transcendence. Why we still need churches today. Studies on a post-secular theory of church construction] (Evangelische Verlagsanstalt, Leipzig, Germany, 2017).

17. J. Habermas, Die Zukunft der menschlichen Natur. Auf dem Weg zu einer liberalen Eugenik? [The future of human nature] (Suhrkamp, Frankfurt am Main, Germany, 2001).

18. S.A. Ivanov, Christians as a designation of citizenship in the Middle Byzantine period, Indoevropejskoe yazykoznanie i klassicheskaya filologiya, 16, 278-282 (2012).

19. J. Koestlé-Cate, Art and the Church: a Fractious Embrace. Ecclesiastical Encounters with Contemporary Art (Routledge, London \& New York, UK, 2016). 
20. K. Kolkunova, Religious studies without religion: modern approaches to the definition of religion, 750 definitions of religion: a history of symbolization and interpretation (Izdatel'stvo Vladimirskogo gosudarstvennogo universiteta, Vladimir, Russia) 139-157 (2014).

21.Zh. Latysheva, Transcending as a subject of socio-philosophical research, D. Sc. Thesis, Social philosophy, Northern (Arctic) Federal University, Arhangel"sk, Russia. (2016).

22. Zh. Latysheva, Religiousness and its expressions in the process of social construction of reality, 750 definitions of religion: a history of symbolization and interpretation, Izdatel'stvo Vladimirskogo gosudarstvennogo universiteta, Vladimir, Russia, 157-195 (2014).

23. N. Luhmann, Real'nost' massmedia, [Die Realitat der Massenmedien], translation from German by Antonovsky, A.Yu. (Kanon+ROOI "Reabilitaciya", Moscow, Russia, 2012).

24. A. McKinnon, Sociological definitions, language games, and the "essence» of religion, Method and theory in the study of religion, 14, 61-83 (2002).

25. Yu.G. Matushanskaya, Autopoiesis of the biblical philosophical and historical concept as the ideological basis of Western civilization, D. Sc. Thesis, Social philosophy (Northern (Arctic) Federal University, Arhangel"sk, Russia, 2015).

26. P.E. Matveev, Moral values (VlGU, Vladimir, Russia, 2004).

27. D. Morgan, Spirit and Medium, in Townsend Chris, ed., The Art of Bill Viola, Thames \& Hudson, London, UK, 88-109 (2004).

28. F. Nietzsche, The fall of idols: favorites (Lenizdat, Saint-Petersburg, Russia, 2014).

29. N.I. Petev, Building personalities in the framework of artificial mythology (on the example of Warhammer 40,000), Bulletin of science of Siberia", series: Humanities, 2, 158-180 (2018).

30. A. Rosen, Art \& Religion in the $21^{\text {st }}$ century (Thames \& Hudson, London, UK, 2017).

31. A.M. Shoufrine, Gnosis, Theophany, Theosis: studies in Clement of Alexandria's appropriation of his background (Biblioteka bogoslova, Moscow, 2013).

32. M. Silantieva, V. Glagolev, and B. Tarasov, Philosophy of cross-cultural communication, International Trends, 15 (2) (49), 64-76 (2017).

33. N. Smart, Worlds Religions (Cambridge University Press, Cambridge, UK, 1998).

34. P.A. Sorokin, The main trends of our time. Chapters from the book, Partnerstvo civilizacij, 1-2, 281-297 (2014).

35. B. Spinoza, Ethics (AST, Moscow, 2001).

36. The official site RIA Novosti, "Arrested suspect in the terrorist attack in the temple in Vladimir", (2009). Information on https://ria.ru/20091211/198618652.html, (Accessed 20 July 2019).

37. E. Voroncova, Theological and religious reception of the sociology of religion by Niklas Luhmann, 750 definitions of religion: a history of symbolization and interpretation (Izdatel'stvo Vladimirskogo gosudarstvennogo universiteta, Vladimir) 127-139 (2014). 